\title{
The Role of Customer Motivation in Mediating Customer Communication and Customer Decision to Use Kartu As of Telkomsel Broadband Services in Kendari of Indonesia
}

\author{
Amri Tanduklangi \\ Postgraduate Study of Business Management, \\ Universitas Halu Oleo Kendari \\ Hayat Yusuf \\ Department of Business and Economics, \\ Universitas Halu Oleo Kendari
}

Doi:10.5901/mjss.2017.v8n2p87

\begin{abstract}
With a growing increase of mobile phone and Internet users through cellular phones, competition among provider companies of mobile broadband services is becoming very tight to win competition among the competitors. This article aims at analyzing the role of customer motivation in mediating the effect of marketing communication on customer decision in using Kartu As of Telkomsel broadband services in Kendari city of Indonesia. The variables used in this study are marketing communication as an independent variable, customer motivation as an intervening variable and customer decision as dependent variable. The data were collected from 100 respondents of Telkomsel mobile broadband customer using Kartu As. Descriptive statistics and structural equation modeling (SEM) analytical tools were used to analyze the items representing each variable. This empirical study shows marketing communication affects customer motivation which in turn it affects customer decision to purchase Kartu As of Telkomsel Services. The results indicated that customer motivation plays an important role in mediating influence of marketing communication on purchase decision in buying prepaid services of Kartu As.
\end{abstract}

Keywords: Kartu As of Telkomsel, Marketing Communication, Customer Motivation, Customer Decisions, SEM Analysis

\section{Introduction}

The rivalry between competitors in telecommunications intensifies, this condition requires each company to implement the right strategy in selling its products. Dewi (2008) suggests modern marketing is not just oriented in a way to develop a good product, provide tariff or an attractive price, and make it affordable for customers, but a company must be able to establish communication with the customers so that it can accommodate their aspirations and desires to meet and satisfy their needs and desires. This is the basis in determining the right marketing communication strategy, so that the company can deliver value to the customer, creating the motivation of customers that drive customer decision and then the company can accept the value of its customers that are comparable to the value that has been given to its customers, in this case is the image of the company, in which it will be able to build the company's reputation.

Telkomsel has been a leading cellular operator in Indonesia since 1995. Among its three main post-paid products and services are Kartu Halo, Kartu Simpati and Kartu As. This provider has always tried to establish a good relationship and communication with the market and to read its trends and meet the market desire through marketing initiatives that will be or already done. Telkomsel has practiced unique and interesting marketing communications in order to establish communication and offers products to customers and prospective customers through advertising, sales promotion, personal selling with direct marketing and through public relations.

In this study, the users of Kartu As, post-paid product of PT Telkomsel were chosen as the research objects, because of the data that we collect shows Kartu As is a product that has the largest share of customer among other 
products of Telkomsel post-paid services in Kendari. Of the total 174138 subscribers of Telkomsel Kendari, $74.26 \%$ are Kartu As customers (data taken from Telkomsel Branch in Kendari). Besides, Kartu As is Telkomsel product which is aiming at teenager segments. Even though, in reality not just teenagers or young souls who are interested in using Kartu As.

Seeing the number of variant forms of marketing communication carried out by Telkomsel, especially on Kartu As product, in this study, the authors wanted to know whether the promotional activities or other forms of marketing communications practiced by Telkomsel influence on the decision making of customers in using Kartu As, and henceforth can be made as inputs for the formulation of corporate strategy of Telkomsel. On the basis of the phenomena mentioned above, then the management of Telkomsel should strive to attract new customers by motivating potential customers to make a purchase through an increase effort of marketing communication strategy so that customers want to buy Kartu As product, or customers of other operators to switch to Kartu As and the current customers stay loyal to Kartu As product.

Kotler and Armstrong (2003) posit that there are many influences that underlie a person in the decision to purchase a product / brand that should be taken into consideration by marketers. Customer buying behavior is often preceded and influenced by many stimuli from outside, either in the form of marketing stimuli and stimuli from other environment.

Customer decisions are actions carried out by individuals, groups, or organizations in order to obtain goods or services. Kotler \& Armstrong (2003) state at the time of decision making, the customer should be able to translate the relevant information in the environment, especially from the seller. Customers are expected to be able to combine the knowledge that he was getting before evaluating the product as the information related to the products to be purchased. It is closely related to the company's strategy in serving customers in terms of both physical and spiritual.

Customer purchasing decisions may include choices about what products or services they buy, what brands they buy, when and where they will buy, as well as other matters relating to how they make that purchase. In determining these purchasing decisions, there are some factors that influence the purchase decision-making, giving considerations that will determine the final decision. Obviously there are many factors that affect a customer in making purchasing decisions. One of the factors that is very interesting in the underlying influence purchasing decisions of customers is a marketing communication, Dawes (2000), Mihart (2012) and Rawal (2013).

Assael (1998) and Irawan (2001) assert that motivation is the driving force in a person who forced him to act. While Handoko (2001) says that motivation is a state in a person who drives the desire of individuals to perform certain desire to achieve the goal. Albari (2002) states that if a person has a high motivation towards a particular object, then he will be compelled to behave in charge of the object. If motivation is low, he will try to avoid the object.

After several Kartu As ads appear with different versions, this product did an advertising strategy as advocated by Assegaf (2013) and Rahmawati (2013) that is quite interesting is to create television advertising by showing commercials Sule, an artist who was bounced name at this time as to create a special attraction for television viewers. In addition, the frequency of appearance of Kartu As ads in various print and electronic media, both also affect the motivation of customers to buy and use the product . In addition to ads, the product also offers various discounts and packages which are all part of sales promotion of Kartu As.

Besides, Kartu As also frequently sponsors various activities both in exhibitions which are often held in the city of Kendari and the activities of the education agency activities such schools and campuses located in the city of Kendari. The above matters will certainly give effect and positive image to customers and prospective customers of Kartu As that would motivate customers to use it as a GSM card selection on their communication needs.

Given the fact that the product share of Kartu As in Kendari by $74.26 \%$ compared with other products of Telkomsel, Simpati and Halo post-paid cards, the researchers intended to find out the influence of marketing communication employed by Kartu As products in all media and other forms of marketing communications to motivate customers and their decision to use this service especially in the area of Kendari. So the study was intended to know the extent of the influence of marketing communications on customer decision to use Kartu As in addition to other influences. Therefore, this study titles The Role of Customer Motivation in Mediating Customer Communication and Customer Decision to Use Kartu As of Telkomsel Broadband Services in Kendari.

\section{Conceptual Framework and Hypotheses}

The construction of this thesis is not only based on the study derived from theories, but also from empirical studies that comes from previous researches that are relevant to this research study. Therefore, the conceptual framework in this thesis is a proof of the hypothesis which is regarded as tentative conclusions of the problem. The mindset starts with looking at the independent variable, marketing communication $(X)$, which consists of five indicators, namely: advertising 
(X1), sales promotion (X2), public relations (X3) direct sales (X4) and personal selling (X5) in which each item is perceived, then the effect of this independent variable will be projected in the dependent variable, that is the consumer motivation (Y1) and customer decision (Y2).

Based on the proposed framework, the relationship between the perceptions of marketing communication, customer behavior and customer decision is seen in the proposed model in Figure 1:

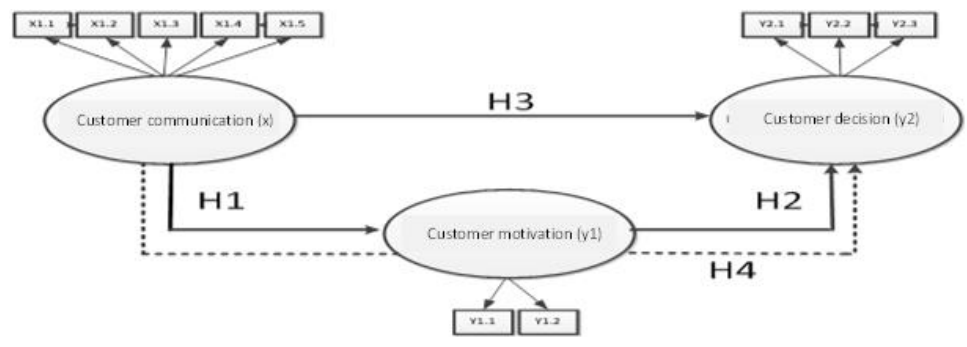

Figure 1: Proposed Model of the Study

\subsection{Research hypothesis}

Based on the description and the conceptual framework of this study, the research hypothesis can be formulated as follows:

$H_{1}$. Marketing Communication has significant effect on Customer Motivation

$\mathrm{H}_{2}$. Customer Motivation has a significant effect on Customer Decisions

$\mathrm{H}_{3}$. Marketing Communications has a significant impact on the Customer Decision

$\mathrm{H}_{4}$. Customer Motivation mediating influence between Marketing Communication and Customer Decision

\section{Methodology}

Based on the nature of the problems and objectives, this study included in the category of explanatory survey research with a descriptive and verification. Hasan (2002) explains that explanatory survey research is intended to explain causeeffect relationship between the variables through hypothesis testing.

The variables studied are marketing communications $(X)$, as exogenous variable, customer motivation variable (Y1) as intervening variable, and the customer's decision as an endogenous variable (Y2). Measurement used of each variable is a questionnaire with 5 options which refers to a Likert scale. In accordance with the hypothesis proposed in this study, then the structural model is employed as suggested by Solimun (2004) that is a model that explains the link between several independent variables or multiple dependent variables. In this study the cause-effect relationship between variables was tested by using SEM (Structural Equations Modeling) tool analysis.

\subsection{Object and Time Research}

The objects of this study are the Customers of Kartu As of Telkomsel in Kendari. The research was conducted for two (2) months period of time. Activities at the first month consist of data collection, processing and analysis. While at the second month activity is compiling research reports.

\subsection{Data and Sample}

Determination of the number of customers using Slovin's sample formula as suggested by Tejada \& Punzalan (2012). To get an idea of customer perception towards Kartu As in the entire area of Kendari, 100 respondents were taken representing the whole districts in the city of Kendari. Where the number of respondents from each of district is determined based on the percentage of the number of Kartu As subscribers in each district of the overall number of the subscribers in Kendari as suggested by Arikunto (2000). 


\subsection{Method of Collecting Data}

The data obtained in this study is collected from distributed questionnaires to 100 Kartu As Telkomsel broadband services customers in Kendari as respondents in this study. Respondents in the study are those customers who had been using the services before the month of September 2013, so that the customers who have been using the services as of October 2013 until now could not be used as respondents. In order to get the respondents, the researchers waited the potential respondents who were conducting transactions at an outlet in the city of Kendari. To decide the respondents, a brief interview was conducted about the residence or domicile of the customer as well as the period of being subscribed to Kartu As. If the result of the brief interview shows that the customer meets the required criteria, such as being a subscriber until September 2013 and domiciled in one of districts in the city of Kendari, then the customer will serve as respondent. Likewise, school children who attended schools and workers in their respective offices were visited in collecting data. Meanwhile, the secondary data obtained through reports, documents, literature and readings related to this research.

\subsection{Scale and Measurement Data}

In collecting the data, the researchers employed questionnaire with a Likert scale of 1 to 5 :

- $\quad$ Answer "strongly disagree" is weighted 1

- Answer "disagree" are given a weight of 2

- Answer "neutral" weighting given 3

- Answer "agree" is weighted 4

- Answer "strongly agree" is weighted 5

\subsection{Operational Definition}

To get an overview over the variables used in research, each of them is defined as follows:

\subsubsection{Marketing Communication $(X)$}

Marketing communication in this study is defined as a combination of advertising, sales promotion, direct marketing, personal selling and public relation that can be controlled by PT. Telkomsel Kendari, which are directed to motivate customers and prospects of Kartu As so that they can decided to use Kartu As of Telkomsel broadband services.

For the common perception, marketing communication is measured by five indicators that have been used by previous studies, namely:

a. Advertising that is an appeal of Kartu As over print and electronic media. This ad also disseminates information about the pre-post card.

b. Sales promotion that is bonuses and sweepstakes for Kartu As subscribers.

c. Direct marketing that is marketing communication of Kartu As to customers either directly through websites or by phones or call centers.

d. Personal selling is personal presentation by the salesperson to provide services and information needed related to Kartu As.

e. Public relation that is active participation of Kartu As in sponsoring events, exhibitions and activities of public concerns.

\subsubsection{Customer Motivation (Y1)}

Customer Motivation in this study is defined as impulse or stimulus for a purpose, need or desire in this case is a boost in making decision to use Kartu As. The types of motivation in using Kartu As are Utilitarian and Hedonistic. Indicators used for customer motivation variable as it has been used previously by Permanasari (2012) are as follows:

a. Utilitarian is the urge to act in this case customers are encouraged to buy Kartu As as his mobile card due to the nature of the product, for examples, product quality, product requirements, and comfort in using the product.

b. Hedonic, a motive that is influenced by emotion, for example, using Kartu As can improve social status, the 
role of brand Kartu As makes a buyer show his/her economic status as well as to follow the trend of the surrounding environment and in general are subjective and symbolic.

\subsubsection{Customer Decision (Y2)}

Customer decision in this study is defined as customer actual action decision to make a purchase of Kartu As, using a variety of criteria that exist in the minds of customers for purchasing.

To reach a common perception, purchasing decision of customers is measured by three indicators that have been used previously by Permanasari (2012) as follows:

a. Product selection in which a customer can make a decision to buy Kartu As because the attributes of a good card.

b. Brand choice is a brand which a customer will have to buy. Kartu As was purchased because of the popularity of the brand of Kartu As itself.

c. Dealer selection in which a customer must decide which one is easily visited, in this case to do the charging of Kartu As pulse.

\subsection{Data Analysis Method}

This study uses a quantitative approach in conducting the data analysis, the analytical methods used in analyzing collected empirical data include descriptive statistical analysis which is intended to analyze and explain the marketing communication, Customer Motivation, and Customer Decision. Then each variable is described in terms of respondents' characteristics and the general description of the object of research that covers number, average, and percentage.

Inferential statistical analysis was selected and used is SEM (Structural Equation Modeling) with the help of software AMOS 18.0. The reason for choosing SEM tool for this research because the model of the research is in the form of multilevel which means that the research comprises more than one endogenous variables (Customer Motivation and Customer Decision).

\section{Results}

\subsection{Descriptive Statistics Analysis}

Descriptive analysis aims to interpret the respondents' answers regarding the frequency distribution of the data that has been collected. An overview of data from the study respondents on the four variables were examined using an average score of respondents described as follows:

\subsection{Marketing Communication}

Based on the results of the questionnaire, the average value of variable marketing communication showed 3.82 , means that the average customer considers that marketing communication of Kartu As is good so as to increase the motivation of the customer in making purchasing decision. These results indicate that the average consumer considers that marketing communications in terms of advertising, sales promotion, direct marketing and personal selling and public relations attract consumers. Intensified marketing communication will increase consumer interest towards Kartu As.

The average value of consumer perception when observed further, showed that there is still a value of 1 and a value of 2 on the item, it could mean that some consumers are still assessing advertising, personal selling, direct marketing and sales promotion as well as public relations that exist in communication marketers of Kartu As is not good, meaning in the eyes of the consumer marketing communication, Kartu As, is less attractive and less attention.

\subsection{Customer Motivation}

From the two existing indicators, utilitarian motivation and hedonic motivation, the result shows that utilitarian motivation has a higher average score. To this, the consumers are encouraged to buy Kartu As due to product quality (e.g., quality of the network and quality of services) provided by Kartu As deemed by the respondents as good or make them highly motivated that can be seen from the average value that indicates a value of 3.83. This result suggests that the tendency of respondents feel good of the product, meaning that they are more interested and motivated for their essential needs 
such as phone, browsing, SMS which are fulfilled by the prepaid brand of Kartu As.

Meanwhile, Hedonic Motivation has an average indicators score of 3.20 , meaning consumers are not fully encouraged to buy Kartu As due to environmental influences, trends and influence the image of youth trends, but more because of the usefulness or benefits.

\subsection{Customer Decision}

The average value of the decision variable is at 3.72, indicating that consumer decision in purchasing Kartu As is at good. Consumer perception of consumer purchasing decision is the largest in number four, it shows that the majority of consumers agree to purchase Kartu As influenced by marketing communication that encourage or motivate consumers to make a purchase. Consumers feel that their decisions are driven by their marketing communications.

Of all the three indicators which have an average score, the highest indicator is the selection of products. This indicator reflects the decision to use Kartu As for quality products and affordable pricing. This is according to consumer entice them to buy prepaid brand Kartu As. The lowest Indicator is at average 3,36 which is at dealer level, specifically recharging via SMS banking. This indicates that the rechargeable of this card is unfavorable in the eyes of consumers, therefore there is a need for training and socialization as well as a better cooperation with the banks in terms of the charging pulse services through this SMS banking.

\subsection{Results of Data Processing}

In testing the hypothesis of direct influence between variables based on the results of data processing, the recapitulation is made as follows:

Table 1.1: Data Processing Results of Direct Effect

\begin{tabular}{|c|c|c|c|c|c|}
\hline Path & Path Coefficient & Critical Ratio & Probability & Hypothesis & Remark \\
\hline $\mathrm{X} \rightarrow \mathrm{Y} 1$ & 0.565 & 3.580 & 0.001 & $\mathrm{H} 1$ & Accepted \\
\hline $\mathrm{Y} 1 \mathrm{->}$ Y2 & 0.953 & 5.534 & 0.001 & $\mathrm{H} 2$ & Accepted \\
\hline $\mathrm{X} \rightarrow \mathrm{Y} 2$ & 0.113 & .900 & 0.368 & $\mathrm{H} 3$ & Rejected \\
\hline
\end{tabular}

Source: Processed Primary Data, 2014

Table 1.2: Data processing Results of Indirect Effect

\begin{tabular}{|c|c|c|c|}
\hline Path & Path Coefficient & Hypothesis & Remark \\
\hline $\mathrm{X} \rightarrow \mathrm{Y}$ 2 through Y1 & 0.539 & $\mathrm{H} 4$ & Accepted \\
\hline
\end{tabular}

Source: Processed Primary Data, 2014

Indirect influence of marketing communication on customer decision mediated by customer motivation to use prepaid brand Kartu As in Kendari by using SEM tool shows a value of 0539 Standardized Indirect Effects.

\section{Discussion}

\subsection{The Influence of Marketing Communication on Customer Motivation of Prepaid Brand Kartu As in Kendari}

Judging from the values of path coefficients and $p$ values, it can be concluded that the hypothesis of a good marketing communication can increase motivation of consumers in purchasing prepaid brand Kartu As. The results suggest the better the marketing communication of the consumer perceived, the higher the consumer motivation in purchasing decision of Kartu As. Thereby it can be concluded that the first hypothesis can be accepted. That indicates the product and services of Telkomsel Kartu As should create different consumer motivation both hedonic and utilitarian in facing the market. For utilitarian, more emphasis should be put on the delivery of the objective benefits of the products. While hedonic raises a person emotion such as joy and pride as well as to follow current trends. 
This study shows that consumers value marketing communication provided by Telkomsel, especially by Kartu As product that can motivate customers. Compatibility of marketing communication (e.g., advertising, sales promotion, direct marketing and personal selling and public relations) which are considered attractive to consumers reflects that marketing communication which are carried by Kartu As was able to motivate consumers both in terms of hedonic motivation and utilitarian motivation to make a purchase of Kartu As. The results support theoretically that the consumer buying behavior is influenced by psychological factor (Kotler, 2007), therefore practiced marketing communication drives good motivation of customers at Kartu As. Good marketing communication with the five key dimensions: advertising, sales promotion, public relations, direct marketing and personal selling Kotler and Armstrong (2008) increase motivation of consumers.

As seen from the data processing, of all the five indicators of marketing communication variable, sales promotion is an indicator that gives the greatest influence, as indicated by the value of its loading factor at 0778 . So that it is very important for Telkomsel to further increase its sales promotion which turned out according to the perception of respondents is still undervalued compared with other indicators in the marketing communication variable. Of all the items of the question about marketing communication, Lottery prize offered by Kartu As turned out to have the lowest value as perceived by the respondents. As previously discussed, this is certainly happening because of rampant fraud in the name of Telkomsel, which sometimes lead to customer losses by transferring sum amount of money or to buy a number of pulses to fraudsters. Therefore Telkomsel must be absolutely clear in the promotion lottery made especially for Kartu As to customers covering the type of lottery, how to enter the lottery, notification mechanism and making gifts for the winners. With this it is expected that the marketing communication will be really contributing positive influence both on the motivation and decision of the customer in using the products and services of Kartu As in the city of Kendari.

The results are consistent with research conducted by Rahayu (2012) which concludes that in order to increase the level of consumer motivation, a corporate must cultivate an effective advertisement that may be a more important factor than any other promotion. It is also supported by research conducted by Joseph (2007) which shows that the ads delivered is to appeal and motivate consumers to seek further information and knowledge about drugs or medical conditions mentioned in the ad.

\subsection{The Influence of Customer Motivation on Customer Decision in Using Kartu As in Kendari}

The value of the path coefficient of the motivation to the decision indicates that a good motivation can boost consumer decision in buying Kartu As. This result suggests a higher perceived motivation of customers is proven to increase customer decision to purchase of Kartu As. It can be concluded that the second hypothesis is acceptable.

The result of data processing showed that motivation that encourages consumers to make a purchase of Kartu As. This research finding supports the result of a study conducted by the Dewi (2008). Motivation has a significant positive effect on purchasing decision. Self-motivation affects someone (customer) in a purchase because it is based on one's self-drive e.g., assessment of the quality and service required of using the goods. Attitude is a stimulant that can cause consumers interested in buying something, of course, the attitude that emerges is a positive one, for example: trust, emotion to have a product with a high awareness of advantages and disadvantages.

According to a research conducted by Utami (2010) motivation partially has significant effect on product purchasing decision and the most dominant variable in influencing the purchasing decision of a product is the motivation variable. Similarly, Aeni (2012) through her study entitled Analysis of Effect of Motivation, Perception, Learning, Attitudes and Campaign Against Buying Decision obtained first hypothesis testing result which shows that the motivation to have a positive influence on the decision to purchase. In addition, Kapoor \& Kulreshta (2009) a driven consumer motivation to buy a product because there is something that moves it, a process of driving a boost so that consumers are motivated to buy a product.

Also, the results of data processing show consumer response towards consumer motivation is considered good. Consumers agreed that motivation is needed to encourage consumer purchasing decision. Of the two existing indicators, utilitarian motivation and hedonic motivation, an indicator that has the highest average was the utilitarian motivation (e.g., choosing Kartu As as driven by the quality of the product, the quality of the network and the services provided by the card, as it can be seen from the average value which shows the value of 3.83 . This result suggests that the tendency of respondents answered Agree, meaning that they are more interested and motivated because of the usefulness or benefits of Kartu As compared to the factors of other people influence or just follow the trend.

The results of this study are supported by research conducted by Dewi (2008) which states that motivation has a significant positive influence on purchase decision. Self-motivation affects consumers in a purchase because it is based on self-motivation, e.g., assessment of quality, price, and convenience usage of the items needed as later shed light on by Mihart (2012). 


\subsection{Influence of Marketing Communication on Customer Decision in Using Prepaid Kartu As in Kendari}

Seen from the path coefficient value of marketing communication towards customer decision, it can be concluded that effective marketing communication can improve the customer decision in purchasing Kartu As, even though, the positive effect is not significant. Hence, it can be concluded that the third hypothesis which states "marketing communication significantly influence the customer decision" is unacceptable (rejected).

Looking at the characteristics of respondents in this study that most respondents are employees (53\%), which may be a chance to see the ads, promotions and other marketing communications is less, so that the effect of communication on the purchasing decision of customers is not significant. In addition to the results of this study, it can be said that the customer of Kartu As in the city of Kendari is the type of smart and rationalistic customers, in the sense that customers do not necessarily directly use Kartu As for an influence of advertising, promotion and marketing communication but it is more of considering the benefits and quality of the prepaid Kartu As.

Besides respondent characteristics and types of customer, the users of Kartu As Kendari can be classified as intelligent, therefore, direct influence of marketing communication on customer decision is not significant due to the concept of the purpose of marketing communication itself. That is the purpose of marketing communication itself consists of three points; as informative that is informing the product to customers, persuasive that builds brand preference as well as a reminder that the products maintain relationships with customers by reminding customers about when, where these products can be obtained. By looking at the purpose of marketing communication, the direct effect that will certainly be felt is emotion or motivation of the customer which would push to make purchasing decisions on Kartu As. Therefore, it is in nature, if the marketing communication has no direct significant impact on customer decision, but has a direct and significant effect on customer motivation.

\subsection{Indirect Influence of Marketing Communication Towards Customer Decision Mediated by Customer Motivation}

Judging from these values it can be concluded that the hypothesis of good marketing communication can improve purchasing decision on buying Kart $u A s$ if it is through customer motivation. The better the marketing communication experienced by the customers the higher the customer purchasing decision in buying Kartu As through customer motivation. Setiadi (2010) states that a good marketing communication is communication that is designing effective message in which the message must be able to attract attention, build interest, arouse desire to buy, and push the purchase action. As it is explained, it can be concluded that the fourth hypothesis can be accepted.

In this study, the indirect effect is stronger than the direct effect. This indicates that good marketing communication will increase customer motivation in which eventually will also increase the purchasing decision.

These results indicate that in order to increase the motivation of customers that will ultimately improve the customer decision to use Kartu As in addition to providing attractive marketing communication, Telkomsel also needs to improve the quality of products, networks and quality of service of prepaid Kartu As, in the hope that the benefit and the quality of that service will in turn stimulate or encourage customers to continue to use Kartu As of Telkomsel for existing customers as well as encourage new customers either completely new as well as the other customers migrating from other mobile products. Therefore, it is clear that the promotion or advertising without the quality coupled with the product itself will not significantly influence the customer decision to use Kartu As of Telkomsel in the city of Kendari.

\subsection{Limitation and Future Research}

The limitation of this study is that the data used in this research is cross sectional data, where the perception of respondents would change in a rapid period of time, so that it needs some time to conduct a longitudinal research in future to determine the company marketing communication strategy in the long term.

\section{Conclusion}

The analytical results indicated that customer motivation plays a role in mediating influence of marketing communication on purchase decision in buying prepaid services of Kartu As. The conclusion can be breakdown into four main points as follows:

1. The better the marketing communication of customer perceived the higher motivation of customers in purchasing decision to buy Kartu As.

2. Effective customer motivation can improve customer decision to buy Kartu As. The higher perceived 
motivation of customers is proven to increase customer decision to purchase Kartu As.

3. Effective marketing communication can improve the customer decision in purchasing prepaid Kartu As of Telkomsel, although the effect is not too significant. This indicates that customers are not necessarily making purchasing decision to use Kartu As without any encouragement or self-motivation in the part of the customer, so that in the end the customer will perform the decision to use the card.

4. Practices of marketing communication of the company will have a positive impact on consumer purchasing decision through customer motivation. The higher the motivation of the customer based on marketing communication practices by company the higher the purchasing decision made by the customers.

\section{Suggestions}

The results of this study indicate that the marketing communication variable can lead to the motivation and ultimately the customer decision. Based on the findings and the conclusions mentioned above, some suggestions are put forward as follows:

1. Telkomsel needs to continue on improving learning or knowledge on the product to all levels of sales teams, both of the team back office and front liners who are in the outlets city of Kendari.

2. Lottery Program held by Telkomsel should be clear about how, announcements and gift-giving mechanism associated with the rampant fraud in the name of Telkomsel, resulting in customer misperception towards sweepstakes and promotions which have been carried out so far.

3. Pulse charging via SMS banking is still low, so it is necessary that a much more intense dissemination to the customers both directly from Telkomsel and from banks that work together with Telkomsel.

4. For future research direction, it is suggested to continue further studies on all other brands of prepaid cards of Telkomsel products and services, so in-depth and perfect studies are made.

\section{References}

Aeni, N. (2012). Analysis of effec of motivation, perception, learning, attitudes and campaign on Albothyl product purchasing decision in Semarang . Journal of Economics, 1-16.

Albari. (2002). Manajemen Perilaku Konsumen Mengenai Penelitian Motivasi [Consumer Behavior Management of Motivation Research]. Jurnal Siasat Bisnis UII, 7(1), 81-95.

Arikunto, S. (2000). Prosedur Penelitian: Suatu Pendekatan Praktek [Procedures of Research: A Practice Approach]. (4th Revised Edition). Jakarta: Rineke Cipta.

Assael, H. (1998). Costumer Behavior and Marketing Action. (6th ed.). Cincinnati: South Western Collage Publishing.

Assegaf, F. (2013). The Effect of Advertising on Consumer Decision Making Through Brand Awareness. Journal EMBA, 1, 866-874.

Dawes, J. R. (2000). Disloyalty: a closer look at non-loyals. Journal of Consumer Marketing, 17(6), 538-549.

Dewi, W. (2008). The Effects of Motivation and Consumer Attitudes Toward Purchase Decision of Honda Motor in West Surabaya Region. journal of Economics 10(1), 30-37.

Handoko, T. H. (2001). Management Personalia dan Sumber Daya Manusia [Personnel Management and Human Resources] (2nd ed.). Yogyakarta: BPFE.

Hasan, M. I. (2002). Pokok-pokok Materi Metodologi Penelitian dan Aplikasinya [Fundamentals of Reseach Method and Application]. Bogor: Ghalia Indonesia.

Irawan, B. S. (2001). Manajemen Pemasaran Moderen [Management of Modern Marketing] . Yogyakarta: Liberthy.

Joseph, D. F. (2007). Consumer opinion and effectiveness of direct-to-comsumer advertising. Journal of Consumer Marketing, 24(5), 283-293.

Kapoor, A., \& Kulshrestha, C. (2009). Consumers' Perceptions: an analytical study of influence of consumer emotions and response. Direct marketing: An international Journal, 3(3), 186-202.

Kotler, P. (2002). Marketing Management, Millenium Edition (10th ed). Boston, MA: Pearson Custom Publishing.

Kotler, P., \& Amstrong, G. (2014). Principles of Marketing (15th Global ed.). Upper Sadle, N.J: Pearson.

Mihart, C. (2012). Impact of Integrated Marketing Communication on Consumer Behavior: Effect on Consumer Decision-Making Process. International Journal of Marketing Studies, 4(2), 121-129.

Permanasari, K. (2012). Influence of Marketing Communication on Customer Decision in Using IM3 through Consumer Motivation in Malang. Malang: Thesis Graduate School of Economics and Business, Universitas Brawijaya.

Rahayu, Y. (2011). Analysis of Communication Channel influence Through Television Media Advertising on Consumer Motivation in Purchasing Nugget. Management E-Journal.

Rahmawati, N. (2013). Influence of Celebrity Endorser in Lux Soap Ad on Consumer Behavior at Sub-district of Dama River Samarinda. EJournal Communication Studies, 1(1), 362-373.

Rawal, P. (2013). AIDA Marketing Communication Model: Stimulating a Purchase Decision in the Minds of the Consumers through a 
Linear Progression of Steps. IRC'S Multididisciplinary Internationa Journal of Research in Social and Management Sciences, 1 (1), 37-44.

Setiadi, N. (2010). Perilaku Konsumen [Consumer Behavior]. Jakarta: Kencana Prenada Media Group.

Solimun. (2004). Multivariate Analysis: Structural Equation Modeling (SEM) Lisrel and Amos, Aplications in Management, Economics of Development, Psychology, Social, Medical and Agro Complex. malang: Fakultas MIPA, Universitas Brawijaya .

Tejada, J. J., \& Punzalan, J. R. (2012). On the Misuse of Slovin's Formula. The Philiphine Statistician, 61(1), 129-136.

Utami, G. A. (2010). The Effect of Motivation, Perception, and Consumer Attitutes on Purchasing Decision of Formula Milk at Sukamaju Village Depok. Jurnal Ekonomi University of Gunadharma. [Online] Available:http://papers.gun adharma.ac.id/files/journals/2/articles/678/public/678-1764-1-PB.pdf (June 10, 2015). 